\section{Report of a New Human Death Caused by a Giant Anteater in Brazil}

\section{To the Editor:}

Anteaters, or tamanduás (anteaters in Brazilian indigenous language), are mammals that feed on termites and ants, using sharp and powerful claws to dig out the insects. There are 4 species, of which the giant anteater or flag anteater (Myrmecophaga tridactyla) is the largest: it can reach $2 \mathrm{~m} / 6 \mathrm{ft}$ in length and $40 \mathrm{~kg}(85 \mathrm{lb})$ in weight (Figure 1). ${ }^{1,2}$

Giant anteaters live in fields and cerrados (savannahlike environments) in Central and South America. They possess poor vision and hearing and are frequently wounded or killed by motor vehicles. ${ }^{1,2}$

Although injuries caused by anteaters are extremely rare due to the lack of aggressiveness of these peaceful and almost blind animals, they can happen when the animals try to defend themselves. ${ }^{3}$ In these situations they may assume an upright posture and use their powerful claws to hurt their opponents.

The forelegs of the giant anteaters have 4 claws, with 3 being particularly well developed (Figure 1). The mammals sometimes "embrace" the victims to use the claws more effectively. Injuries to humans usually occur only when the animals are provoked, hunted, or handled for scientific proposes. ${ }^{3}$ The claws can cause serious tissue laceration, copious bleeding, and death. ${ }^{3}$
A 54-year-old man died after being attacked by a giant anteater in the rural area of Diamantina, Minas Gerais State, Brazil (Bom Sucesso neighborhood, latitude 18 16'1.72" and longitude $\left.43^{\circ} 32^{\prime} 16.64^{\prime \prime}\right)$. The victim experienced the attack when he was looking for his dogs, which had cornered the animal in a forested area close to his home.

Soldiers and fire department personnel responded to a call from the victim's relatives. They found the victim lying with punctures and lacerated wounds in all 4 limbs and severe bleeding from the right thigh, 4 hours after the injury occurred (Figure 2). The firefighters attempted to stabilize the victim with saline to maintain blood volume, but the patient experienced cardiac arrest and died from hypovolemic shock before air transport was conducted.

From the report of medical examiner, the corpse presented 2 perforating-contused wounds in the anterior regions and proximal of the right forearm, each measuring approximately $2.0 \mathrm{~cm}$ in length (Figure 3). Another perforating-contused wound was present in the lateral and proximal right leg, measuring about $3.0 \mathrm{~cm}$. A third wound $2.0 \mathrm{~cm}$ in diameter was located in the upper third of the right thigh (Figure 3). This wound had allowed intense bleeding into the subcutaneous tissue, muscle lesions, and complete section in the region of the femoral artery into the adductor canal. These wounds are consistent with injuries seen in other humans who have been injured by anteaters. In fact, the similarity of lesions seen in humans who have been injured by anteaters is

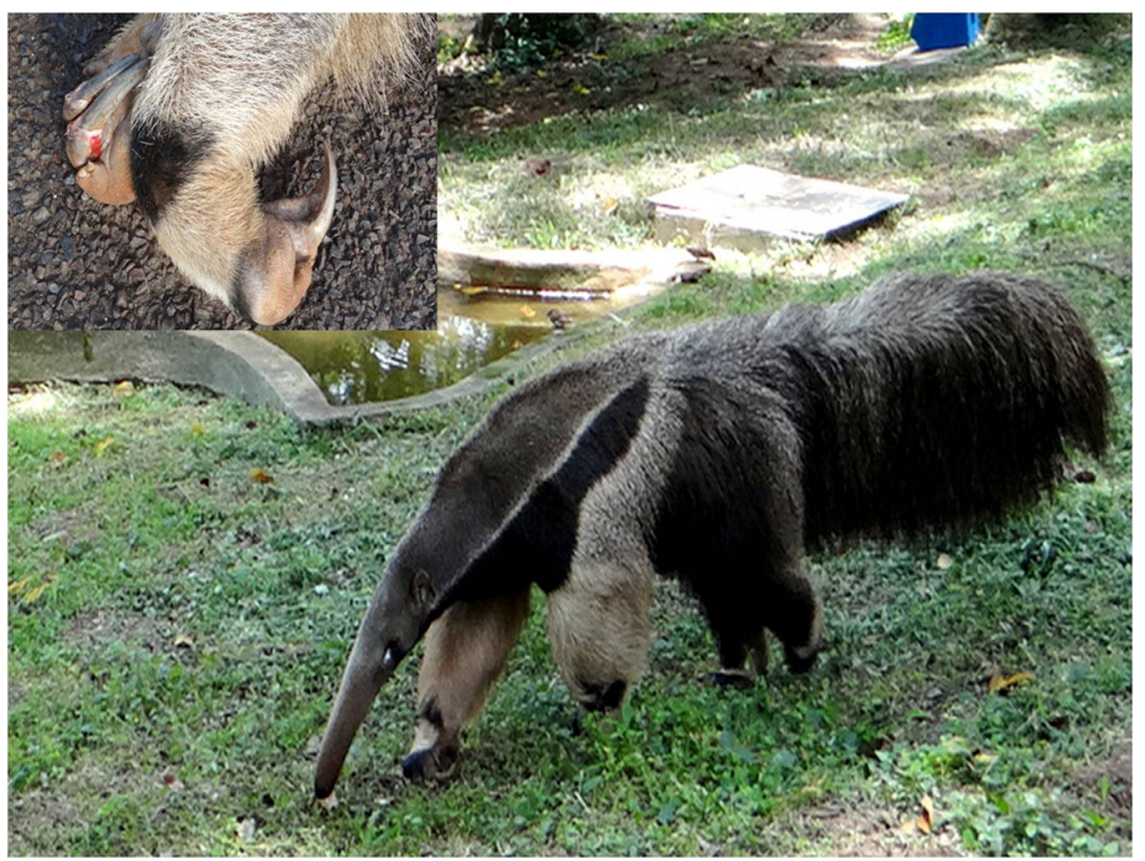

Figure 1. Giant anteater (Myrmecophaga tridactyla). In the detail: the claws of the forelegs. Photos by Vidal Haddad Junior. 


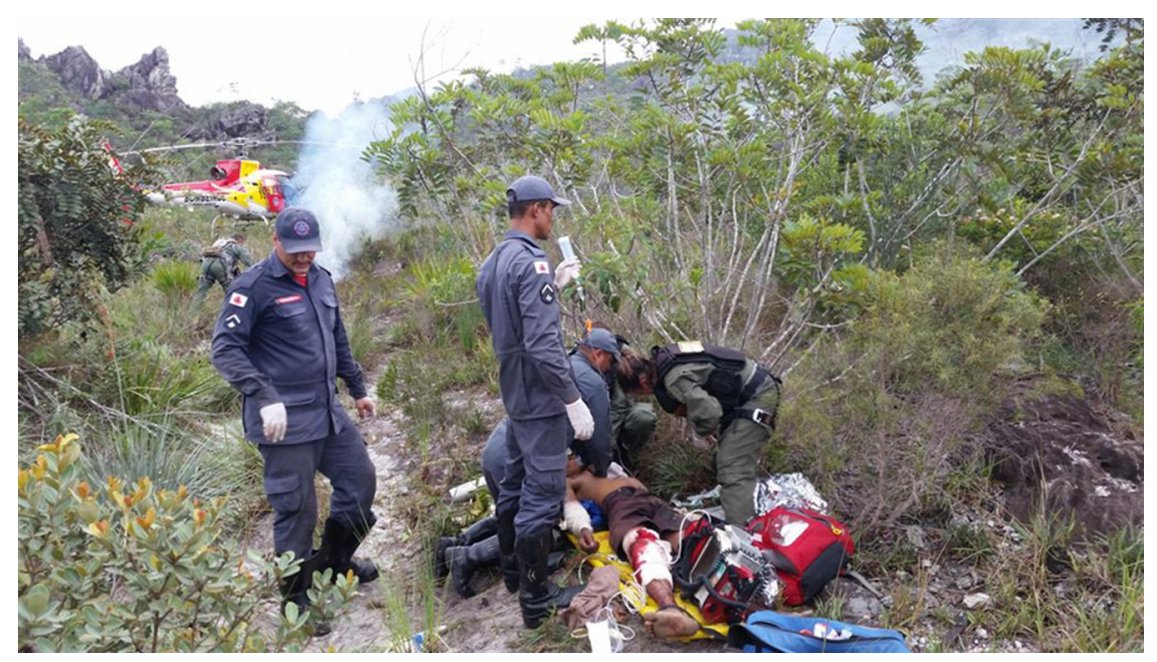

Figure 2. Urgent care rendered by firefighters at the site of the accident. Note the copious bleeding from the right thigh of the victim (causal to the victim's death) and the presence of air transport. Photo by 3rd Battalion Firefighters in Diamantina, Brazil.

quite remarkable. Lacerations and perforations have been seen in the femoral arteries or branches and the popliteal artery, causing massive bleeding and death by hypovolemic shock. First aid with maintenance of vital parameters should be the priority in the immediate treatment of such injuries.
This new report of death caused by an anteater reinforces clinical and epidemiological aspects described in earlier reports and clearly demonstrates how these animals can cause injuries when threatened by humans. ${ }^{3}$ Increasing contact with humans can result from the destruction of the animal's traditional environments

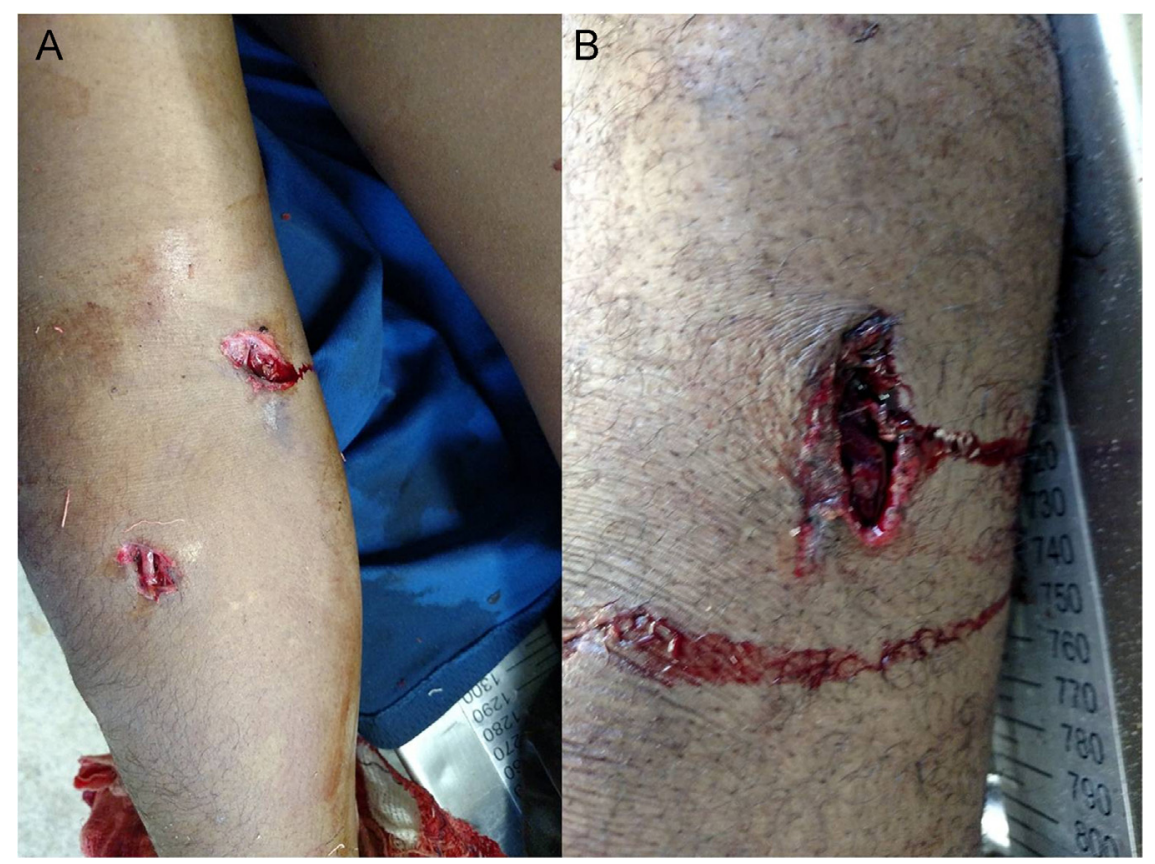

Figure 3. A, 2 perforating-contused wounds in the anterior regions and proximal of the right forearm, measuring approximately $2.0 \mathrm{~cm}$ in length each. B, This wound of $2.0 \mathrm{~cm}$ in diameter located in the upper third of the right thigh was responsible for the perforation of the femoral artery and the death. Photos by Jenerson França Nunes. 
and increase the risk of injury. Campaigns to preserve these beautiful animals may also prevent serious injuries and deaths of human beings.

Acknowledgment: We are thankful to Lieutenant Paulo César Ferreira of the 3a Operating Company-Diamantina Fire Department, Minas Gerais State, Brazil for sharing information and images concerning first aid treatment of the victim at the accident site.

Vidal Haddad Junior, MD, MSc, PhD Botucatu Medical School, São Paulo State University São Paulo, Brazil

Jenerson França Nunes Medical Examiner, Diamantina, Minas Gerais, Brazil

\section{References}

1. Gardner AL. Order pilosa. In: Wilson DE, Reeder DM, eds. Mammal Species of the World: A Taxonomic and Geographic Reference. 3rd ed. Baltimore, MD: Johns Hopkins University Press; 2005:100-103.

2. Rodrigues FHG, MedriI M, Miranda-Mourão G, CamiloAlves CS, Mourão G. Anteater behavior and ecology. In: Vizcaíno SF, Loughry $\mathrm{WJ}$, eds. The Biology of the Xenarthra Gainesville, FL: University Press of Florida; 2008:257-268.

3. Haddad V Jr, Reckziegel GC, Garrone Neto D, Pimentel FL. Human death caused by a giant anteater (Myrmecophaga trydactila) in Brazil. Wilderness Environ Med. 2014;25:446-449. 